\title{
Household solid waste generation and characteristics in Cape Haitian city, Republic of Haiti
}

\author{
Féniel Philippe*, Marc Culot \\ Laboratory of Microbial Ecology and Waste Water Treatment, FUSAGx, Avenue Marechal Juin, 27 Building 52, 5030 Gembloux, Belgium
}

\section{A R T I C L E I N F O}

\section{Article history:}

Received 13 October 2008

Received in revised form 26 June 2009

Accepted 29 June 2009

Available online $\mathrm{xxx}$

\section{Keywords:}

Household solid waste

Waste generation

Waste characteristics

Waste management

Haiti

\begin{abstract}
A B S T R A C T
Because of a lack of planning and of the poor HSW (household solid waste) management, the municipal authorities of Cape Haitian are unable to cope with the rapid growth of the city or to ensure a pleasant living environment for its residents. Indeed no HSW management plan has been drawn for Cape Haitian. The main difficulty in the development of a HSW management system lies in the lack of knowledge of the composition and the characteristics of the waste that is generated in the city as is the case of the whole country. HSW management is very poor and there is no valorisation policy. The objective of this study was to carry out a field survey of the HSW generation profile in the city of Cape Haitian in order to have relevant data enabling better management and valorisation of HSW. The city's residential wards have been categorized in three different types (I, II and III) representing high, medium and low socioeconomic groups in the city respectively. HSW generation has been quantified and characterized by the ward's type. Results show that HSW generation rate is $0.21 \mathrm{~kg} / \mathrm{capita} /$ day. The organic matter represents $65.5 \%$ of waste by weight. This is similar to the results from developing countries. With a moisture level of $55.6 \%$, an LCV of $1395 \mathrm{kcal} / \mathrm{kg}$ and a C/N ratio of 31:1, composting of the HSW and applying it on the land seem to be the best HSW treatments for Cape Haitian in a sustainable development perspective. As there is no previous study of this kind in Haitian urban areas, this report may be taken as baseline for other Haitian cities.
\end{abstract}

(C) 2009 Elsevier B.V. All rights reserved.

\section{Introduction}

As a result of rapid urbanization and changes in consumption of many cities in developing countries, waste generation has increased. However, the waste generated is, in most cases, not properly managed. Hence, this has huge consequences in terms of collection, disposal and the elimination of waste (Thonart et al., 2005; Moghadam et al., 2009). In almost all developing countries, city solid waste constitutes a hazard, be it from the ecological point of view or the public health point of view. Almost everywhere, there is a distinct lack of policy on efficient waste collection and a total absence of its treatment (Culot et al., 1999). Many experts from various cities in developing countries have expressed serious concerns about improper waste treatment and disposal in these countries (Berkun et al., 2005; Pokhrel and Viraraghavan, 2005; Barton et al., 2008; Chung and Lo, 2008; Imam et al., 2008; Sharholy et al., 2008). In most developing countries, solid waste management is undertaken by the local authorities. These services include waste

\footnotetext{
* Corresponding author. Tel.: +32(0)81 6223 87/61 52 95; fax: +32 (0)81615957.

E-mail addresses: philippe.f@fsagx.ac.be, fenielp@yahoo.fr (F. Philippe), culot.m@fsagx.ac.be (M. Culot).
}

collection (either from households or district collection points) to final disposal. However, the low financial base and human resource capacity of these local authorities mean that in most cases they are only able to provide a limited service (Barton et al., 2008).

Inadequate management of solid waste in most cities of developing countries leads to problems that impair human and animal health and ultimately result in economic, environmental and biological losses (Wilson et al., 2006; Kapepula et al., 2007; Sharholy et al., 2008).

Haitian cities face many problems due to improper management of household waste (MDE, 1996). Indeed, even with the best of intentions, municipal authorities are unable to establish and implement an efficient management plan mainly because of the lack of understanding of waste generation and its characteristics. Authorities tend to implement management plans and use equipment which are not adapted to the realities of Haitian cities. This study is fundamental for producing data on the quantity and characteristics of HSW in Cape Haitian as well as developing adequate managing strategies. The main objectives of this study were to make a systematic analysis of household solid waste leading to quantification of the amount of HSW generated from studied area and to determine its composition so as to highlight some specific features capable of promoting research on recovery of Cape Haitian's solid waste. Furthermore, as far as the authors are aware in the relevant body 


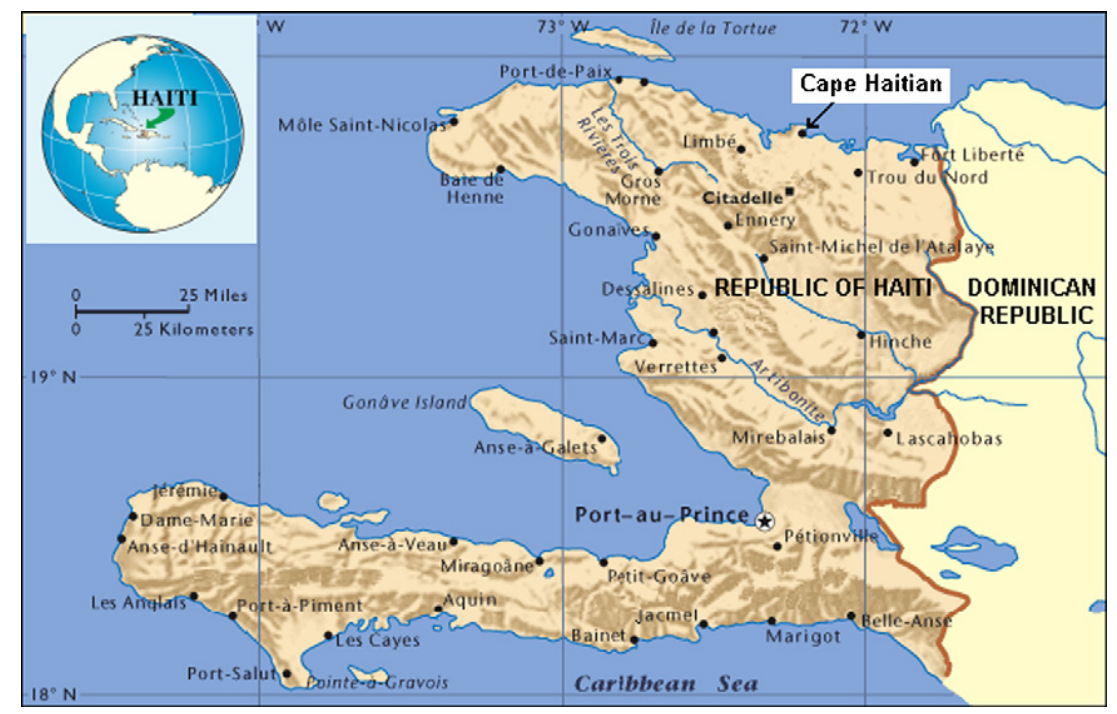

Fig. 1. Location of the city of Cape Haitian in the Republic of Haiti.

of literature, this kind of study has not yet been reported from Haiti.

\subsection{Data study area}

This study was conducted in the city of Cape Haitian, located in the northern part of Haiti between latitudes $19^{\circ} 43^{\prime}$ and $19^{\circ} 45^{\prime} \mathrm{N}$ and between longitudes $72^{\circ} 10^{\prime}$ and $72^{\circ} 14^{\prime} \mathrm{W}$ (Fig. 1 ). With its population of 225,740 people (IHSI, 2007) and an area of $11.94 \mathrm{~km}^{2}$ the city of Cape Haitian is the second largest agglomeration of the Republic of Haiti after the nation's capital (2,245,000 people).

Although situated in the Caribbean, the Republic of Haiti has many similarities with various African countries especially in terms of HSW management. Indeed, despite efforts put in place by the authorities several years ago in order to improve HSW management in Haitian cities, the situation remains alarming due to many limiting factors. These factors are of a technical, economical, social and cultural nature. In Haitian cities, the waste collection rate is not more than 50\% (MDE, 2005). Non-collected waste is generally thrown in drainage canals, in open field and buildings under construction. Haiti, being regularly hit by torrential rains, this waste obstructs the drainage network, which consequently intensifies the destructive power of the rain waters (Thonart et al., 1999). Currently, there is neither a HSW recovery nor a recycling programme. The collected waste is thrown in discharges which are poorly managed. Burning the discharges is a common practice in Haiti (CWBI, 1999). HSW in Haiti has very little heavy metals. But in big cities of Haiti there are poor people who pick up the waste. These groups tend to stay closer or even on the discharges. These areas expose these groups to epidemiological and hygienic problems due to the biological activity of the discharges.

In addition to environmental and public health problems in Cape Haitian, poor HSW management paralyses the city's economic development which has always been based on the tourism sector. In fact, Cape Haitian is a potential tourist city especially because of its historical monuments, some of which are included on the UNESCO World Heritage list as universal symbols of liberty, as they are the first monuments to be constructed by black slaves who had gained their freedom (UNESCO, 2009).

Cape Haitian is facing great difficulties because of high rates of urbanization in Haiti due to rural exodus. The annual Cape Haitian population growth rate is about 5.1\% (IHSI, 2007). In similar conditions, waste generation increased quickly in such a way that the city authorities were overwhelmed. On the other hand, when waste generated by a community is well managed, it can be converted into valuable resources (Ojeda-Benitez et al., 2003). Due to the lack of proper HSW management, burning waste in the backyard is a widespread practice in Haiti in general and in particular, in Cape Haitian. In the new high-income wards, some households try to compost the organic waste matter. However, it is on a very small scale and without appropriate techniques (MDE, 2005). In Cape Haitian, more than $72 \%$ of households are not concerned by official waste collection. In such circumstances, children evacuate HSW in the evening, throwing the waste anywhere and hence creating unauthorized dumps in the city. Most often, these unauthorized dumps are found close to markets, constructions (sites?) and drains. As there is no segregation of waste at the source and no efficient collection, no recovery is currently applied to HSW in Cape Haitian.

However, a good understanding of HSW stream (generation and characteristics) could allow local authorities to better plan waste management.

\section{Methodology}

Firstly, a study involving the assessment of documents and records relating to municipal solid waste in Haiti has been conducted. Census and economic planning data have also been studied to obtain background information as well as data to enable construction of a conceptual model on HSW management in Cape Haitian.

Table 1

Main characteristics of the three types of wards identified.

\begin{tabular}{|c|c|c|c|}
\hline Characteristics & Type I wards & Type II wards & Type III wards \\
\hline Population density & Less than 10,000 inhabitants $/ \mathrm{km}^{2}$ & From 10,000 to 25,000 inhabitants $/ \mathrm{km}^{2}$ & More than 25,000 inhabitants $/ \mathrm{km}^{2}$ \\
\hline Economic level & High & Medium & Low \\
\hline Direct access to public roads & All buildings & All buildings & Access to passageway of about $1 \mathrm{~m}$ wide (Koridò) \\
\hline Access to utilities & Yes & Yes & No \\
\hline
\end{tabular}


Table 2

Population distribution of Cape Haitian in the three types of wards.

\begin{tabular}{lccccr}
\hline Ward type & \multicolumn{2}{c}{ Area } & & & \multicolumn{2}{c}{ Population ${ }^{\mathrm{a}}$} \\
\cline { 2 - 3 } \cline { 5 - 6 } & $\mathrm{km}^{2}$ & $\%$ & & Inhabitants & $\%$ \\
\hline Type I & 2.06 & 20.39 & & 10,371 & 4.60 \\
Type II & 2.67 & 26.49 & & 55,061 & 24.39 \\
Type III & 5.35 & 53.12 & & 160,308 & 71.01 \\
Total & 10.08 & 100 & & 225,740 & 100 \\
\hline
\end{tabular}

${ }^{a}$ From the results of the last population census (IHSI, 2007).

Table 3

Calendar of garbage bag deposit and HSW collection.

\begin{tabular}{lllllll}
\hline & Monday & Tuesday & Wednesday & Thursday & Friday & Saturday \\
\hline 1st week & $\mathrm{D}_{1}$ & $\mathrm{D}_{2}$ & $\mathrm{D}_{3}$ & $\mathrm{D}_{1} \mathrm{C}_{1}$ & $\mathrm{D}_{2} \mathrm{C}_{2}$ & $\mathrm{D}_{3} \mathrm{C}_{3}$ \\
2nd week & $\mathrm{D}_{1} \mathrm{C}_{1}$ & $\mathrm{D}_{2} \mathrm{C}_{2}$ & $\mathrm{D}_{3} \mathrm{C}_{3}$ & $\mathrm{D}_{1} \mathrm{C}_{1}$ & $\mathrm{D}_{2} \mathrm{C}_{2}$ & $\mathrm{D}_{3} \mathrm{C}_{3}$ \\
3rd week & $\mathrm{D}_{1} \mathrm{C}_{1}$ & $\mathrm{D}_{2} \mathrm{C}_{2}$ & $\mathrm{D}_{3} \mathrm{C}_{3}$ & $\mathrm{D}_{1} \mathrm{C}_{1}$ & $\mathrm{D}_{2} \mathrm{C}_{2}$ & $\mathrm{D}_{3} \mathrm{C}_{3}$ \\
4th week & $\mathrm{C}_{1}$ & $\mathrm{C}_{2}$ & $\mathrm{C}_{3}$ & & & \\
\hline
\end{tabular}

$\mathrm{D}_{x}$ : deposit garbage bags in households of type $x$ wards. $\mathrm{C}_{x}$ : collection of HSW from households of type $x$ wards.

All residential wards of Cape Haitian city were selected in order to generalize the findings for the entire urban area. Researchers have shown that HSW quality and quantity in cities of developing countries could vary from one suburb to another depending on the population's socio-economic level (Parizeau et al., 2006; Yousuf and Rahman, 2007; Sujauddin et al., 2008), Cape Haitian's wards were classified into three types (types I, II and III) representing high, medium and low socio-economic groups in the city (Table 1). Results were then balanced considering population size in the three types of suburbs. Types of ward were characterized by the following criteria: population density, economic level, direct access of buildings to public roads and access to utilities (electricity, telephone, and drinking water) (Table 2). Suburbs were marked out by analyzing the city morphology realized from orthophotoplans available at CNIGS, field prospections and a socio-economic survey. In the three ward types a household survey was conducted in an attempt to extract both qualitative and quantitative data about HSW generation. The sample to be studied was determined by means of a stratified sampling. Fifty buildings were randomly chosen in each suburb type.

The chosen buildings were then visited in order to verify whether there were households inside and to seek the approval from the head of the household to answer the sampling questionnaire and also to get his/her consent for the collection of the household waste for the study.

A sample of 116 households was retained for the study: 36 in type I wards, 42 in type II wards and 38 in type III wards. The 34 which were not retained mainly due to HSW collection schedule which was not suitable to them.

Furthermore, households had received 601 garbage bags to gather all waste generated. Waste collection was held twice a week according to schedule (Table 3) for three weeks (21 days) for weighing, sorting and other analyses.
However, during the 1 st week of collection, it was found that the garbage bags were filled mostly by former waste. In fact, people had the opportunity to get rid of waste kept at home for several days or several weeks. Therefore, the 1st week of waste that was collected was not considered and the real start of the study was postponed to the following week.

For each type of ward's collection day, waste collected was progressively poured in a $20 \mathrm{dm}^{3}$ bin and weighed. Daily per capita solid waste generation for a ward type was then calculated as:

waste/capita/day $=\frac{\sum_{i=1}^{i=6} W i}{21 P}$

$W_{i}$ is the total weight obtained for a day collection and $P$ is the population in surveyed households.

Waste density was then determined by assessing the volumes.

For each collection, wastes were mixed; a sample of about $100 \mathrm{~kg}$ was retained for sorting and analysis.

The determination of percentage of carbon, hydrogen and nitrogen was conducted according to ASTM E777 and E778 standards in the laboratory at the National University of Haiti (UEH).

The moisture level was determined after drying samples for $24 \mathrm{~h}$ at $105^{\circ} \mathrm{C}$ in an oven. The moisture content was calculated as follows:

moisture content $(\%)=\frac{W_{i}-W_{f}}{W_{i}} \times 100$

$W_{i}$ and $W_{f}$ are the initial and final weights, respectively.

Volatile matter was determined after burning samples at $550^{\circ} \mathrm{C}$ for $2 \mathrm{~h}$ in a muffle furnace. The volatile solids content was calculated by calculating the difference between the weight before and after heating.

Finally, lower calorific value (LCV) was calculated from high calorific value (HCV) using these equations (Eqs. (1) and (2)) (Khan and Abu-Ghararah, 1991):

$\mathrm{HCV}=0.051(\mathrm{OMW}+3.6 \mathrm{PW})+0.352(\mathrm{PLW}) \quad(\mathrm{MJ} / \mathrm{kg})$

$\mathrm{LCV}=\mathrm{HCV}-6(M+9 H) \quad(\mathrm{kcal} / \mathrm{kg})$

where OMW = weight in \% of organic matter; PW = weight in \% of paper/cardboard; PLW = weight in \% of plastic. $M$ and $H$ are the total waste moisture and the total hydrogen contained in HSW respectively.

Waste toxicity was not taken into account because according to several studies, Haitian cities' HSW are of very low toxicity (MDE, 2005).

\section{Results and discussion}

\subsection{HSW generation}

Results of solid waste collected from households over the survey period are summarized in Table 4 . Results reveal that the rate of waste generation varies in the different types of wards. The trend is gradually increasing with the increase of the socioeconomic level. The waste generation rate was found to be 0.39

Table 4

Cape Haitian HSW generation.

\begin{tabular}{|c|c|c|c|c|c|c|c|c|}
\hline \multirow[t]{2}{*}{ Type of ward } & \multirow{2}{*}{$\begin{array}{l}\text { Population in surveyed } \\
\text { households }\end{array}$} & \multirow[t]{2}{*}{ Production (kg) } & \multirow[t]{2}{*}{ Period (day) } & \multirow[t]{2}{*}{ Ratio (kg/capita/day) } & \multicolumn{2}{|c|}{ Variation (kg/capita/day) } & \multirow[t]{2}{*}{ Total population } & \multirow{2}{*}{$\begin{array}{l}\text { Total waste } \\
\text { generation } \\
\text { (kg/day) }\end{array}$} \\
\hline & & & & & Min & Max & & \\
\hline Type I & 234 & 1905 & 21 & 0.39 & 0.34 & 0.56 & 10,371 & 4,045 \\
\hline Type II & 247 & 1679 & 21 & 0.32 & 0.28 & 0.41 & 55,061 & 17,620 \\
\hline Type III & 218 & 731 & 21 & 0.16 & 0.13 & 0.18 & 160,308 & 25,649 \\
\hline Total & & & & 0.21 & & & 225,740 & 47,405 \\
\hline
\end{tabular}


Table 5

Comparison of the ratio of Cape Haitian HSW generation with other cities' or countries' ratio.

\begin{tabular}{|c|c|c|c|c|}
\hline City/country & Ratio (kg/capita/day) & References & GDPa (PPP) (\$ US/capita) & Rank $^{\mathrm{a}}$ GDP \\
\hline Santiago/Cuba & 0.09 & Binder and Mosler (2007) & 3,900 & 117 \\
\hline Cape Haitian/Haiti & 0.21 & This study & 1,800 & 155 \\
\hline Chittagong/Bangladesh & 0.25 & Sujauddin et al. (2008) & 2,200 & 143 \\
\hline Gaborone/Botswana & 0.33 & Bolaane and Ali (2004) & 11,400 & 62 \\
\hline Siem Reap/Cambodia & 0.34 & Parizeau et al. (2006) & 2,600 & 135 \\
\hline Kinshasa/Congo & 0.5 & Nzuzi (2008) & 1,300 & 168 \\
\hline Abuja/Nigeria & 0.58 & Imam et al. (2008) & 1,400 & 167 \\
\hline Mexicali/Mexico & 0.59 & Ojeda-Benitez et al. (2003) & 10,600 & 65 \\
\hline Dar es Salaam/Tanzania & 0.70 & Mbuligwe and Kassenga (2004) & 800 & 187 \\
\hline Bogotá/Colombia & 0.72 & MINEFI-DREE/TRÉSOR (2004) & 8,400 & 76 \\
\hline Morocco & 0.75 & Soudi and Chrifi (2008) & 4,400 & 112 \\
\hline Mauritius & 1.3 & Mohee (2002) & 13,500 & 54 \\
\hline USA & 2.1 & EPA (2006) & 43,500 & 6 \\
\hline
\end{tabular}

a The annual gross domestic product per inhabitant is given here in purchasing power parity (PPP) after CIA (2008).

and $0.32 \mathrm{~kg} /$ capita/day in the types I and II wards respectively and $0.16 \mathrm{~kg} / \mathrm{capita} /$ day in the type III wards. The relation between waste generation and socio-economic level is discussed by various authors (Medina, 1997; Bandara et al., 2007; Sujauddin et al., 2008). In Cape Haitian, this trend is essentially due to the number of meals per day. Actually, in type I wards, $91.2 \%$ of the population have three meals a day while in type III wards, $76.3 \%$ of the population have one meal a day.

The weighted average according to type wards population has shown a daily per capita rate of $0.21 \mathrm{~kg}$ for the entire city. Haiti's low economic development might explain this low HSW production compared to industrialized countries. However the average HSW production in Cape Haitian is low even when it is compared with other cities or countries that have a GDP similar to Haiti's (Table 5).

\subsection{HSW composition}

Cape Haitian HSW composition shows a higher content of organic matter by weight, 65.5\% (Table 6). According to several researchers, this is the case in several cities in developing countries: Iran: 80-88\% (Moghadam et al., 2009), Gaborone/Botswana: $68 \%$ (Bolaane and Ali, 2004), India: 40-60\% (Sharholy et al., 2008), Nigeria: 52-65\% (Imam et al., 2008), Jordan: 54-78\% (Abu-Qdais, 2007).

In Cape Haitian, the high rate of organic matter could be explained essentially by food habit of population which consumes many green bananas and tubers (yam, sweet potato and tarot) peeled directly in the kitchen. In type II wards, the percentage of organic matter is lower (49\%) because these wards consist mostly of historic downtown, and these households consume more packaged products. A program of recovery of recyclable wastes should then be considered in type II wards for some materials such as plastic, paper/cardboard and glass.

\subsection{HSW characterization}

The Cape Haitian HSW has a bulk density of $0.26 \mathrm{ton} / \mathrm{m}^{3}$ (Table 7). Density is an important criterion in waste management

\section{Table 6}

Average composition of HSW in Cape Haitian (\% of weight).

\begin{tabular}{lcccc}
\hline Category & Type I wards & Type II wards & Type III wards & Average \\
\hline Organic matter & 66.6 & 49 & 71.1 & 65.5 \\
Plastics & 6.3 & 11.6 & 8.6 & 9.2 \\
Paper/cardboard & 10.4 & 14.6 & 7.0 & 9.0 \\
Glass & 7.2 & 10.1 & 4.2 & 5.8 \\
Metals & 3.7 & 6.2 & 1.3 & 2.6 \\
Other & 5.8 & 8.5 & 7.8 & 7.9 \\
Total & 100 & 100 & 100 & 100 \\
\hline
\end{tabular}

for planning the estimation of storage, collection and transportation, as well as land filling of waste. As other cities in developing countries, the Cape Haitian HSW density is very high because of the high percentage of organic matter. Moreover, the high moisture content obtained for the Cape Haitian HSW is due to this organic matter. Results show that moisture content is about 56\% (Table 7).

Incineration could also be considered because the LCV calculated with plastic and paper/cardboard allows for this possibility. The LCV of Cape Haitian HSW is $1395 \mathrm{kcal} / \mathrm{kg}$. However, to facilitate self-combustion of waste, it requires $1202 \mathrm{kcal} / \mathrm{kg}$ of LCV and at least $1503 \mathrm{kcal} / \mathrm{kg}$ of LCV for power generation (Tiquia et al., 1996). Therefore, incineration is not the best method for the treatment of Cape Haitian HSW because it requires centres for waste sorting and without energy recovery the municipality cannot afford such an investment.

\section{Valorisation of HSW}

Till now there is no HSW valorisation policy for Cape Haitian. However, scavenging and collecting directly from households is a widespread activity in Cape Haitian.

\subsection{Potentially recyclable waste}

The recyclable matter (paper/cardboard, plastic, glass, metals) contained in Cape Haitian's HSW was determined from generated quantities per type of wards and represented $27.6 \%, 42.5 \%$ and $21.1 \%$ for wards types I, II and III respectively. The recyclable matter for the whole city represented $26.6 \%$. It is negligible even when compared to other developing countries: Mostaganem/Algeria: 31.1\% (Guermoud et al., 2009); Amman/Jordan: 31\% (Abu-Qudais and Abu-Qdais, 2000); Istanbul/Turkey: 34\% (Metin et al., 2003). On the contrary, the recyclable rate found in ward type II requires our

Table 7

Physicochemical analysis of Cape Haitian HSW.

\begin{tabular}{lcccc}
\hline Parameter & Type I wards & Type II wards & Type III wards & $\begin{array}{c}\text { Average for } \\
\text { the city }\end{array}$ \\
\hline${\text { Bulk density (ton } / \mathrm{m}^{3} \text { ) }}$ & 0.27 & 0.22 & 0.28 & 0.26 \\
Moisture $^{\mathrm{a}} \%$ ) & 57.4 & 46 & 59.2 & 55.9 \\
Hydrogen (\%) & 2 & 2.1 & 2.5 & 2.4 \\
Carbon (\% by weight) & 51.5 & 41.3 & 56.7 & 52.7 \\
Nitrogen (\%/by weight) & 1.5 & 1.5 & 1.8 & 1.7 \\
C/N & $35: 1$ & $28: 1$ & $32: 1$ & $31: 1$ \\
Volatile matter (\%) & 77 & 75 & 81 & 79 \\
Ashes & 23 & 25 & 19 & 21 \\
HCV (kcal/kg) & 1801 & 2217 & 1900 & 1973 \\
LCV (kcal/kg) & 1348 & 1827 & 1410 & 1395 \\
\hline
\end{tabular}

\footnotetext{
a Moisture was determined only for organic matter.
} 
attention because in these wards $76 \%$ of households were ready to sort the waste.

\subsection{Organic matter valorisation}

Results on chemical composition of Cape Haitian HSW (Table 7) showed that the $\mathrm{C} / \mathrm{N}$ ratio is $31: 1$. The ideal $\mathrm{C} / \mathrm{N}$ ratio for composting is between $25: 1$ and $35: 1$. The $\mathrm{C} / \mathrm{N}$ ratio of $30: 1$ was found to be optimal (Choi, 1999). Then, composting in order to produce a soil amendment is the most suitable treatment for Cape Haitian HSW. Furthermore, many experiments conclude that 50-60\% moisture content is suitable for efficient composting (McKinley and Vestal, 1984; Tiquia et al., 1996). However, it should be noted that the wastes collected in this study were not exposed to rain; however, $59 \%$ of the HSW from the surveyed households are exposed to rain, hence increasing the waste humidity during rainy periods. In composting, high moisture content could influence gaseous exchange by limiting diffusion and thus restricting oxygen utilisation by microorganisms, resulting in decreased microbial activity. This condition could lead to the production of a biologically unstable and poor-quality end-product (Tiquia et al., 1996). Therefore, composting in Cape Haitian should be considered where HSW is not exposed to rain, sorted at source and properly collected.

Nevertheless, the composting potential depends on other characteristics such as concentration of carbon as well as nitrogen and the $\mathrm{C} / \mathrm{N}$ ratio.

\section{Conclusion}

In Cape Haitian, even though HSW are thrown everywhere in unauthorized dumps, there is no great need to reduce HSW generation. Compared to other cities in developing countries, Cape Haitian HSW generation is lower. Cape Haitian authorities simply need to design and implement a management plan that takes into account the HSW characteristics as well as the city's particularity. Moreover these wastes have very interesting characteristics that could be exploited in a valorisation perspective. Therefore, there is need to alert the population to sort out the waste at the source. The segregation of waste at source and promotion of recycling or reuse of segregated materials reduces the quantity of waste and the burden on landfills and provides raw materials for manufacturers.

The composition (65.5\% of organic matter) and characteristics of Cape Haitian HSW is suitable for organic treatment. Composting the organic matter and using the compost as an organic fertilizer is a suitable way of managing HSW in Cape Haitian.

Furthermore, at the Northern Department, there is a substantial market for compost in the area of Saint Raphael, dedicated mainly to vegetable crops, about $80 \mathrm{~km}$ from Cape Haitian.

Nevertheless, a specific investigation concerning the market for the composting product is always necessary before planning compost production and further studies must be conducted to determine nature and quality of the compost to be produced.

Although this study was conducted in the longest season (the wet season), it is imperative that the HSW stream survey be carried out in the contrasting season, i.e. in the dry season (July-August).

In addition, considering that other studies carried out in Haitian cities have shown that wastes from commercial premises are mostly rich in organic matter (MDE, 2005), the HSW composting programme should be studied to consider commercial waste.

\section{Acknowledgements}

The authors acknowledge support through the CGRI Scholarship. We also would like to thank authorities of the Cape Haitian municipalities, CNIGS, FDS and FAMV of UEH for their collaboration.

\section{References}

Abu-Qdais HA. Techno-economic assessment of municipal solid waste management in Jordan. Waste Management 2007;27(11):1666-72.

Abu-Qudais MD, Abu-Qdais HA. Energy content of municipal solid waste in Jordan and its potential utilization. Energy Conversion and Management 2000;41(9):983-91.

Bandara NJGJ, Hettiaratchi JPA, Wirasinghe SC, Pilapiiya S. Relation of waste generation and composition to socio-economic factors: a case study. Environmental Monitoring Assessment 2007;135(1-3):31-9.

Barton JR, Issias I, Stentiford EI. Carbon-making the right choice for waste management in developing countries. Waste Management 2008;28:690-8.

Berkun M, Aras E, Nemlioglu S. Disposal of solid waste in Istanbul and along the Black Sea coast of Turkey. Waste Management 2005;25(8):847-55.

Binder CR, Mosler H-J. Waste-resource flows of short-lived goods in households of Santiago de Cuba. Resources Conservation \& Recycling 2007;51: 256-83.

Bolaane B, Ali M. Sampling household waste at source: lessons learnt in Gaborone. Waste Management and Research 2004;22(3):142-8.

Choi K. Optimal operating parameters in the composting of swine manure with wastepaper. Journal of Environmental Science and Health 1999;34(6):97587.

Chung SS, Lo CWH. Local waste management constraints and waste administrators in China. Waste Management 2008;28(2):272-81.

CIA. The 2008 world factbook; 2008, https://www.cia.gov/library/publications/theworld-factbook/ [accessed 07.15.08].

Culot M, Bastien C, Etienne M, Becker H. Evaluation des actions à mener en vue de l'assainissement global (déchets et eaux) de la ville de Kigali. 1999.

CWBI. Atlas des décharges d'ordures ménagères dans les pays en développement: Haiti; 1999, http://www2.ulg.ac.be/cwbi/projets/atlas/pays/Haiti/haiti.htm [accessed 04.23.09].

EPA. Municipal solid waste generation, recycling and disposal in the United States: facts and figures for 2006; 2006, http://www.epa.gov/epaoswer/nonhw/muncpl/pubs/msw06.pdf [retrieved 07.22.08].

Guermoud N, Ouadjnia F, Abdelmalek F, Taleb F, Addou A. Municipal solid waste in Mostaganem city (Western Algeria). Waste Management 2009;29(2):896902.

IHSI. IVème Recensement (RGPH): Résultats définitifs, ensemble du pays. Port-auPrince; 2007.

Imam A, Mohammed B, Wilson DC, Cheeseman CR. Solid waste management in Abuja, Nigeria. Waste Management 2008;28(2):468-72.

Kapepula K-M, Colson G, Sabri K, Thonart P. A multiple criteria analysis for household solid waste management in the urban community of Dakar. Waste Management 2007;27:1690-705.

Khan MZA, Abu-Ghararah ZH. New approaches for estimating energy content in MSW. ASCE Journal of Environmental Engineering 1991;117(3): 376-80.

Mbuligwe SE, Kassenga GR. Feasibility and strategies for anaerobic digestion of solid waste for energy production in Dar es Salaam city, Tanzania. Resources Conservation \& Recycling 2004;42:183-203.

McKinley VL, Vestal JR. Biokinetic analyses of adaptation and succession: microbial activity in composting municipal sewage sludge. Applied and Environmental Microbiology 1984;47(5):933-41.

MDE. Rapport sur la gestion des ordures ménagères en Haïti. Port-au-Prince: MDE; 1996.

MDE. Colloque: Partenariats pour la gestion des résidus solides. Port-au-Prince: MDE; 2005.

Medina M. The effect of income on municipal solid waste generation rates for countries of varying levels of economic development: a model. Journal of Solid Waste Technology and Management 1997;24(3):149-55.

Metin E, Eröztürk A, Neyim C. Solid waste management practices and review of recovery and recycling operations in Turkey. Waste Management 2003;23(5): 425-32.

MINEFI-DREE/TRÉSOR. la gestion des déchets en Colombie; 2004, http://www.dree. org/documents/223/73404.pdf [retrieved 08.01.08].

Moghadam MRA, Mokhtarani N, Mokhtarani B. Municipal solid waste management in Rasht City, Iran. Waste Management 2009;29(1):485-9.

Mohee R. Assessing the recovery potential of solid waste in Mauritius. Resources Conservation \& Recycling 2002;36(1):34-43.

Nzuzi FL. kinshasa: ville et environement. Kinshasa: l'Harmattan; 2008.

Ojeda-Benitez S, Vega CA, Ramírez-Barreto ME. Characterization and quantification of household solid wastes in a Mexican city. Resources Conservation \& Recycling 2003;39:211-22.

Parizeau K, Maclaren V, Chanthy L. Waste characterization as an element of waste management planning: lessons learned from a study in Siem Reap, Cambodia. Resources Conservation \& Recycling 2006;49:110-28.

Pokhrel D, Viraraghavan T. Municipal solid waste management in Nepal: practices and challenges. Waste Management 2005;25:555-62.

Sharholy M, Ahmad K, Mahmood G, Trivedi RC. Municipal solid waste management in Indian cities. Waste Management 2008;28(2):459-67.

Soudi B, Chrifi H. Options de gestion des déchets solides municipaux adaptées aux contextes des pays du sud. Rabat-Agdal: Enda Magreb/Enda Tiers Monde; 2008.

Sujauddin M, Huda SMS, Hoque ATMR. Household solid waste characteristics and management in Chittagong, Bangladesh. Waste Management 2008;28: 1688-95. 
Thonart P, Diabaté SI, Hiligsmann S, Lardinois M. Guide pratique sur la gestion des déchets ménagers et des sites d'enfouissement technique dans les pays du sud. Canada: IEPF; 2005.

Thonart P, Lardinois M, Kapepula D, Hiligsmann S, Destain J. La problématique de la gestion des déchets ménagers en République d'Haïti. Port-au-Prince, Haiti; 1999.

Tiquia SM, Tam NFY, Hodgkiss IJ. Microbial activities during composting of spent pig-manure sawdust at different moisture contents. Bioresource Technology 1996;55(3):201-6.
UNESCO, 2009. National History Park -Citadel, Sans Souci, Ramiers. http://whc unesco.org/en/list/180/ (accessed 20 July 2009).

Wilson DC, Velis C, Cheeseman C. Role of informal sector recycling in waste management in developing countries. Habitat International 2006;30: 797-808.

Yousuf TB, Rahman M. Monitoring quantity and characteristics of municipal solid waste in Dhaka City. Environmental Monitoring Assessment 2007;135(1-3):3-11. 